To cite: ME Addazi-Koom "'He beat me, and the state did nothing about it": An African perspective on the due diligence standard and state responsibility for domestic violence in international law' (2019) 19 African Human Rights Law Journal 624-652

http://dx.doi.org/10.17159/1996-2096/2019/v19n2a4

\title{
'He beat me, and the state did nothing about it': An African perspective on the due diligence standard and state responsibility for domestic violence in international law
}

\author{
Maame Efua Addadzi-Koom* \\ Lecturer in Law, Kwame Nkrumah University of Science and Technology, \\ Ghana \\ https://orcid.org/0000-0003-1296-6315
}

\section{Summary}

State responsibility for human rights violations by private individuals as well as the cataloguing of domestic violence as a human rights violation in international law are emerging concepts being filtered through regional and international courts, quasi-judicial and treaty-monitoring bodies. These judicial and quasi-judicial bodies delineate a framework for determining state obligations with regard to domestic violence under international human rights law through the due diligence standard. The Economic Community of West African States Community Court of Justice in 2018 had its first opportunity to offer insights into its jurisprudence regarding state responsibility for domestic violence in international law. This article contributes to the dialogue on the standard for state responsibility together with the forms of domestic violence acts that are appropriate to warrant intervention from an African perspective. It focuses on how the ECOWAS Community Court of Justice has incorporated the due diligence standard and examines its potential as a legal tool to ascertain the nature of state obligations pertaining to those manifestations of domestic violence against women that are worthy of international intervention in the West African sub-region and Africa as a whole.

\footnotetext{
* LLB (Ghana); BL (Ghana); LLM (USA); maameeakoom@gmail.com
} 
Key words: domestic violence; due diligence; ECOWAS Court; state responsibility; West Africa

\section{Introduction}

State responsibility for violations of human rights by private or nonstate actors and the acknowledgment of domestic violence as an infringement of human rights are developing concepts in international law. ${ }^{1}$ International and regional courts, quasi-judicial and treatymonitoring bodies through their decisions, therefore, develop a due diligence jurisprudence aimed at clearly setting out what the due diligence standard entails and delineate a framework to determine state obligations with regard to domestic violence against women in compliance with the standard. ${ }^{2}$

In May 2018 the Economic Community of West African States (ECOWAS) Community Court of Justice (ECCJ) gave a landmark decision in favour of the complainants in IHRDA \& WARDC (on behalf of Mary Sunday) $v$ The Federal Republic of Nigeria ${ }^{3}$ - the first ever domestic violence case to be brought before the Court. The case is celebrated for setting the tone for state responsibility to victims of domestic violence regarding their right to a fair trial. Yet, the ECCJ did not find the defendant state to be in violation of the complainant's right to freedom from discrimination and gender-based violence. This decision engenders legal discourse on the standard for state responsibility as well as the forms of domestic violence acts that are appropriate to warrant intervention at international law.

Against this backdrop, the article reviews the Mary Sunday case which offers preliminary insights into the jurisprudence of the ECC) that is developing regarding domestic violence. The case is also seminal to our understanding of the expansive notion of state responsibility for violations by private actors based on the due diligence principle. The ECCJ for the first time made reference to the due diligence standard in relation to domestic violence. Focusing on the due diligence standard, the article analyses how the standard is used in the Mary Sunday case by the ECCJ. The article further explores its potential as a tool to define and assess the obligations of states pertaining to those manifestations of domestic violence against women that are worthy of international intervention in the West African sub-region and Africa as a whole.

The article proceeds in five parts: Part 1 looks at state responsibility and the due diligence standard as applicable to domestic violence in

1 L Hasselbacher 'State obligations regarding domestic violence: The European Court of Human Rights, due diligence, and the international legal minimums of protection' (2010) 8 Northwestern Journal of International Human Rights 190.

2 As above; J Goldscheid \& D J Liebowitz 'Due diligence and gender violence: Parsing its power and its perils' (2015) 48 Cornell International Law Journal 301. 
international law; part 2 gives a brief overview of the ECOWAS Court, particularly its jurisdiction and procedures regarding human rights; part 3 focuses on the Mary Sunday case, including the facts and issues raised and the judgment; part 4 reviews and analyses the Mary Sunday case through the lens of state responsibility and the due diligence standard in order to ascertain the ECCJ's jurisprudence on the subject as well as the potential impact of the due diligence standard in the African human rights regime in relation to domestic violence. Part 5 concludes the article.

\section{State responsibility, due diligence standard and domestic violence in international law}

\subsection{State responsibility}

State responsibility is a topic that has been subjected to many layers of classification: imputability, direct and indirect responsibility, and responsibility for particular groups such as state organs, insurrectional groups and private individuals. ${ }^{4}$ A state incurs responsibility when its actions or omissions constitute an internationally wrongful act. ${ }^{5}$ To put it differently, a breach or violation of international law by a state entails its international responsibility. ${ }^{6}$

State responsibility arises under two conditions: First, when the conduct of a state is 'attributable to the state under international law $^{\prime},{ }^{7}$ that is when an act or omission is imputable to the state or deemed to have been carried out by the state and, second, when the conduct of a state 'constitutes a breach of international obligation of the state', 8 that is a breach of a duty imposed by an international juridical standard. ${ }^{9}$

The attribution of conduct to a state for international responsibility as seen in the Articles on Responsibility of States for Internationally Wrongful Acts (ARSIWA) is strict in nature. That is, a state is held responsible for acts imputable to it regardless of its intention whether the act or omission was in good faith, bad faith or negligent - as long as the act or omission is internationally wrongful. ${ }^{10}$ This is

$4 \quad$ I Brownlie Principles of public international law (1990) 446.

5 Art 1 Articles on Responsibility of States for Internationally Wrongful Acts 2001 (ARSIWA).

6 'A violation of international law is a definitive act which would, by itself, directly involve responsibility.' Italy $v$ France (Preliminary objections) (1923) PCIJ Ser A/B/, No 74 (Phosphate in Morocco case). 'Responsibility is the necessary corollary of a right. All rights of an international character involve international responsibility. Responsibility results in the duty to make reparation if the obligation in question is not met.' Great Britain v Spain (1925) 2 RIAA 615641 (Spanish zone of Morocco claims).

7 Art 2 ARSIWA (n 5).

8 As above.

9 A Abass International law: Text, cases and materials (2014). United States $v$ Mexico (1931) RIAA 1 (Dickson Car Wheel Company case). 
what is known as the objective responsibility of a state. Most courts, tribunals and other quasi-judicial bodies in the international sphere are biased towards objective responsibility. ${ }^{11}$

However, at customary international law subjective responsibility is considered (also known as the fault theory) in addition to objective responsibility. Subjective responsibility, unlike objective responsibility, takes cognisance of the intention of a state for an action or omission before assigning responsibility. Subjective responsibility will therefore ask whether the state intentionally acted unlawfully (dolus) or whether it was negligent (culpa). ${ }^{12}$ This notwithstanding, subjective responsibility should not be mistaken for the failure of a state to exercise due diligence as is prudent in a particular situation. This is because the failure by a state to employ due diligence in its actions will give rise to a strict liability even if it acted or omitted to act in good faith.

The state in itself is not a living person capable of acting on its own. That is why state responsibility is imputed to the state through the actions and inactions of certain groups of persons. ARSIWA lists the entities the actions or inactions of which are attributable to states and further gives the circumstances under which those acts or omissions merit attribution. ${ }^{13}$ State organs, insurrectional groups ${ }^{14}$ and private individuals are the special groups whose actions of omissions may be attributable to the state. This article's main focus is on private individuals as they are the direct perpetrators of domestic violence. The article also looks at state organs in part, because of the growing theory and debate surrounding state responsibility for domestic violence acts carried out by private individuals. Thus, these two categories of actors are considered.

The conduct of private persons usually is not attributable to the state except in two circumstances, namely, where private individuals act on the instruction of the state or are directed or controlled by the state, ${ }^{15}$ and where there is an absence or default of official authorities such that private persons or groups of persons exercise governmental authority in the circumstances. ${ }^{16}$ All the same, the conduct of private persons acting strictly in their private capacity may incur state responsibility where the state failed to prevent such conduct. The responsibility of the state in such cases arises not as a direct result of the private person's conduct but indirectly as a result of the failure of

10 As above.

11 As above.

12 As above. Some international law scholars are of the view that the distinction between objective and subjective responsibility is neither here nor there. Rather than working towards a cross-cutting theory of state responsibility, each case should be decided on its own merits for it is "both difficult and illusory to seek a single acceptable dominant theory of responsibility'. Abass (n 9).

13 Arts 4-11 ARSIWA (n 5).

14 Art 10 ARSIWA. Art 11 of ARSIWA mentions imputability by the acknowledgment of actions by the state.

15 Art 8 ARSIWA (n 5).

16 Art 9 ARSIWA. 
the state to prevent such conduct. ${ }^{17}$ For example, the domestic violence acts of a private person may incur state responsibility not because a state is directly responsible for the acts of domestic violence carried out privately by that individual, but because the state failed to exercise due diligence to prevent or prosecute that private individual that perpetuated the domestic violence acts.

On the other hand, the conduct of state organs, whether legislative, executive, judicial or other conduct, is attributable to the state regardless of the position the person or entity holds in the organisation of the state. ${ }^{18}$ Actions of persons who are not organs of state but are empowered by the law of the state to exercise elements of governmental authority are also imputable to the state. ${ }^{19}$ The actions of organs of the state, or person or entity empowered to exercise elements of government authority, are attributable to the state even if the actions are ultra vires, so long as the entity was acting in its official capacity. ${ }^{20}$ It is important to distinguish acts of state officials acting in their private capacity from ultra vires acts of state officials acting in their official capacity. The former ordinarily is not attributable to the state while the latter is.

The international jurisprudence on state responsibility further acknowledges positive obligations of states arising from the negative rights of individuals. By this, the impact of negative rights, such as the right to life of persons, which traditionally was viewed as only limiting a state's interference in a person's right to life, has now been expanded to impose a positive obligation on states to put in place appropriate measures to protect and ensure that individuals enjoy their right to life. The failure of a state to do so is likely to incur international responsibility. ${ }^{21}$ Similarly, the right to be free from torture, inhuman and degrading treatment and abuse, though negative in nature, imposes a positive obligation on the state to ensure that individuals are protected from violence and abuse even within the private setting. Where a state fails to prevent acts of violence in the private sphere, such as acts of domestic violence, its failure is interpreted as complicity, and what would otherwise have been a purely private act independent of the state, turns into 'a constructive act of the state' for which the state will be held accountable. $^{22}$

The due diligence standard discussed in the next part builds on the above-stated concord between the positive obligation of states and the enjoyment of negative rights by its citizens with respect to

17 J Crawford \& S Olleson 'The character and forms of international responsibility' in MD Evans (ed) International law (2014) 443456.

18 Art 4 ARSIWA (n 5).

19 Art 5 ARSIWA.

20 Art 7 ARSIWA.

21 Hasselbacher (n 1) 192.

22 As above; BC Meyersfeld 'Reconceptualising domestic violence in international law' (2003) 67 Albany Law Review 371. 
domestic violence, by expanding state responsibility to cover private acts of private individuals.

\subsection{Due diligence standard}

The due diligence standard is premised on the question of what measure of diligence, responsibility or prudence exercised by a state is deemed reasonable enough for it to have executed its obligations. ${ }^{23}$ The Inter-American Court case of Velasquez Rodriguez $v$ Honduras (Velasquez case) $^{24}$ was the global first to detail the due diligence standard. In this case, Angel Manfredo Velasquez Rodriguez, a graduate student, was kidnapped from a parking lot by armed men in civilian clothes. His kidnapping and disappearance were one of a series of disappearances in Honduras between 1981 and 1984. It was common knowledge that the abductions had been carried out by military personnel and other agents of the state acting on state orders. The targets of the abductions were persons suspected of being a threat to national security. In this landmark case, the central issue before the Inter-American Court was whether Honduras's obligation under the American Convention was merely to 'respect' the rights of individuals by refraining from violating them, or whether Honduras had an obligation to take positive steps to protect individuals from human rights violations by non-state actors. ${ }^{25}$

The Inter-American Court found evidence supporting the fact that the kidnappers were undercover agents of the state. ${ }^{26}$ The Court further indicated that even if it had not found such evidence, 'the failure of the [s]tate apparatus to act ... is a failure on the part of Honduras to fulfil the duties it assumed under [a]rticle 1(1) of the [American] Convention'. ${ }^{27}$ The Court found the obligation of Honduras to be dual in nature based on the language of article 1(1) of the American Convention: 'The [s]tate [p]arties to this Convention undertake to respect the rights and freedoms recognised herein and to ensure to all persons subject to their jurisdiction the free and full exercise of those rights and freedoms. ${ }^{28}$

First, the obligation that state parties must 'respect' individual rights and freedoms means that states are to refrain from directly violating individual rights. Second, the obligation of state parties to 'ensure' means that states are to mobilise all government apparatus to prevent, investigate and punish any violation of individual rights and

Meyersfeld (n 22).

Inter-American Court of Human Rights (29 July 1988) Ser C No 4.

HJ Steiner, P Alston \& R Goodman International human rights in context: Law, politics, morals (2007) 214.

26 Velasquez case (n 24) para 182.

27 As above.

28 My emphasis. 
freedoms and, where feasible, restore those rights or provide adequate compensation for any harm suffered. ${ }^{29}$

The Inter-American Court explained that the second obligation of state parties to 'ensure' under article 1(1) of the Convention was not limited to state actors but may extend to non-state actors: ${ }^{30}$

An illegal act which violates human rights and which is initially not directly imputable to a state (for example, because it is the act of a private person or because the person responsible has not been identified) can lead to international responsibility of the state, not because of the act itself, but because of the lack of due diligence to prevent the violation or respond to it as required by the Convention ${ }^{31} \ldots$. The violation can be established even if the identity of the individual perpetrator is unknown. What is decisive is whether a violation of the rights recognised by the Convention has occurred with the support or the acquiescence of the government, or whether the state has allowed the act to take place without taking measures to prevent it or to punish those responsible.

The Court further explained the basic duties that constitute the standard of due diligence. The basic duties are often referred to as the '5Ps': prevent, protect against, prosecute, punish and provide reparation. ${ }^{32}$ That is, the

legal duty to take reasonable steps to prevent human rights violations and to use the means at its disposal to carry out a serious investigation of violations committed within its jurisdiction, identify those responsible, to impose the appropriate punishment and to ensure the victim adequate compensation.

The duty to prevent human rights violations means that states are to take all reasonable measures - legal, political, administrative and cultural - to protect individual rights. ${ }^{34}$ States discharge this duty by drafting and adopting specific national legislation against violations of human rights; developing policies and action plans; and undertaking awareness-raising campaigns, training for professional groups such as prosecutors, the police and members of the judiciary. ${ }^{35}$ The existence of violations, however, does not necessarily mean that the state has failed in its duty to prevent abuses. ${ }^{36}$

29 Velasquez case (n 24) (my emphasis).

30 Para 173 Velasquez case.

31 Para 172 Velasquez case (n 24) (my emphasis).

32 Goldscheid \& Liebowitz (n 2).

33 Para 174 Velasquez case (n 24 above). Similar language is found in Human Rights Council 'Accelerating efforts to eliminate all forms of violence against women: Ensuring due diligence in prevention' (2010) A/HRC/RES/14/12 para 1. Also, UN General Assembly 'Intensification of efforts to eliminate all forms of violence against women' (2013) A/RES/67/144 para 11.

34 L Henkin et al Human rights (2009) 851, citing R Coomaraswamy 'Report of the Special Rapporteur on Violence Against Women, Its Causes and Consequences' UN Doc E/CN.4/1996/53 (1996) para 54. Human Rights Council (n 33).

35 Y Ertrük 'Integration of the human rights of women and the gender perspective: Violence against women: The due diligence standard as a tool for the elimination of violence against women' (2006) E/CN.4/2006/61 Report para 61.

Coomaraswamy (n 34). 
The duty to protect includes providing legal assistance, health care, counselling centres, shelters, restraining orders and financial aid to victims of violence. 37 The proper implementation of these protective measures prevents the continuous victimisation of victims of violence.

The duty to punish requires states to conduct thorough, objective and serious investigations such that violations are punished. Anything short of this is a failure on the part of the state. However, as in the case of the duty to prevent, the fact that an investigation did not yield sufficient results does not mean the state has failed in its duty to investigate. ${ }^{38}$ This is because the due diligence obligation is one of means and not results, although states are required to undertake all diligent measures that have the potential to actually prevent or eliminate abuse. ${ }^{39}$

The duty to provide sufficient reparations requires states to ensure that victims of violence are adequately compensated.

Ultimately, the due diligence standard holds states accountable for their actions and inactions, especially with regard to human rights issues, even in instances where violations were carried out by private individuals. ${ }^{40}$ It changes the traditional notion that states can only be responsible for human rights violations of their agents.

Although the Velasquez case used the due diligence standard to extend state responsibility for violations by private persons, the violations in issue occurred in the public domain, hence leaving the whole realm of private violations against women by private persons uncharted. ${ }^{41}$ Driven by the need to widen state responsibility in the private sphere, especially in relation to violence against women, feminists used the due diligence standard as applied in the Velasquez case as a launch pad to disintegrate the public/private divide that for so long shrouded international intervention in matters of violence against women. Through advocating and politicising the supposed private violence, the feminist understanding of the due diligence standard permeated legal texts and scholarship and the jurisprudence of other international and regional human rights systems. ${ }^{42}$

Yakin Ertürk, former UN Special Rapporteur on Violence Against Women, Its Causes and Consequences, endorsed the feminist understanding of the due diligence standard in her report on the due

\footnotetext{
37 Ertrük (n 35).

38 Coomaraswamy (n 34); Ertrük (n 35).

39 R Manjoo 'Report of the Special Rapporteur on Violence Against Women, Its Causes and Consequences' (2013) A/HRC/23/49 para 72, citing Opuz v Turkey App No 33401/02, Eur CtHR (2009) para 136; Goldscheid \& Liebowitz (n 2).

40 PG Moral \& MA Dersnah 'A feminist challenge to the gendered politics of the public/ private divide: On due diligence, domestic violence, and citizenship' (2014) 18 Citizenship Studies 661.
}

41 As above.

42 As above. 
diligence standard as a tool for the elimination of violence against women: 43

The due diligence standard has helped to challenge the liberal doctrine of state responsibility with regard to violation in the 'private sphere'. This meant that the state, by failing to respond to intimate/domestic violence, can be held responsible for not fulfilling its obligation to protect and punish in a non-discriminatory way and can be charged as an accomplice to private violations. On the other hand, using due diligence to filter private acts through state responsibility has left the individual perpetrator of an act of private violence not directly responsible under international law, thus maintaining a separate regime of responsibility for private as opposed to public acts.

Ertürk further identified some underlying principles of the due diligence standard of which states must be mindful and should apply, namely, the fact that the obligation of states to exercise due diligence is a non-delegable duty; non-discrimination in the application of the due diligence standard; ${ }^{44}$ that due diligence must be exercised in good faith; and that measures to prevent and protect women from violence must be founded on accurate empirical data. ${ }^{45}$

In sum, the due diligence standard imposes on states a positive obligation to use all reasonable measures appropriate to eliminate violations of human rights and impunity. It also serves as a liaison between the conventional relationship in international law between the state and its agents, on the one hand, and the relationship between the state and the dealings of private persons, on the other. ${ }^{46}$ The next part of the article investigates domestic violence in international law, highlighting its shift from the historical public/ private divide to its current status.

\subsection{Domestic violence in international law}

The majority of instances of gender-based violence that women experience at various stages of their lives are domestic in nature 'occurring in the home, perpetrated by those to whom the woman is closest'. ${ }^{4}$ Despite the domesticity of the violence, it is a universal tool of oppression that transcends borders and cultures. ${ }^{48}$ Thus, there is an emerging jurisprudence for the recognition of domestic violence as a human rights violation at the international level. ${ }^{49}$ This move has resulted in a continuing discourse aimed at re-conceptualising domestic violence, that is, to ascertain an identifiable genus of

43 Ertrük (n 35).

44 The same level of commitment to due diligence should be applied in cases of violence against women as in other forms of violence.

45 Ertrük (n 35).

46 E Abi-Mershed 'Due diligence and the fight against gender-based violence in the Inter-American system' in C Benninger-Budel (ed) Due diligence and its application to protect women from violence (2009) 127128.

47 Coomaraswamy (n 34) para 54.

48 Henkin et al (n 34); Meyersfeld (n 22).

49 Hasselbacher (n 1); Meyersfeld (n 22). 
domestic violence acts that can be classified as international human rights violations under international law.

Traditionally, domestic violence has been recognised as a private matter to be addressed within the confines of the home. The longstanding private nature of domestic violence acts was premised on the traditional roles that women played in society - limited to the home which makes violations against women a matter that is concealed within the private sphere, void of state or international intrusion. 50

For the longest time, a major flaw with the public/private dichotomy was the lack of regulation of the private sphere. Nonregulation of matters within the private sphere and a lack of institutional protection often led to the family being a 'cradle of violence', women often being at the receiving end. ${ }^{5 T}$ Theoretically, the public/private dichotomy (where public referred to the realm of government politics, economics and the workplace and private referred to the family) frowns upon the perpetration of domestic violence in the private sphere. This assertion is premised on the work of John Stuart Mill, the philosopher who partly shaped the concept of public/private duality. Mill was of the view that state intervention in private freedoms should be at its barest minimum except where it is necessary to prevent harm to others. ${ }^{52}$ This is why using the private leg of the dichotomy to perpetuate domestic violence with impunity is a non-starter. By politicising and internationalising domestic violence, the erstwhile 'private violence' is plunged into the public sphere by reconceptualising domestic violence with reference to states, which is in line with the foundational concepts of the dichotomy. International and regional human rights courts, feminist theorists and organisations have contributed towards the process of shifting the recognition of domestic violence from the private domain into the public sphere of international human rights law.

In the early 1990s the United Nations (UN) Committee on the Elimination of All Forms of Discrimination against Women (CEDAW Committee) issued General Recommendation 19 which construed CEDAW $^{53}$ as applicable to violence against women occurring both in public and in private. ${ }^{54}$ Thus, although 'domestic violence' was not specifically mentioned in CEDAW, it was deemed applicable to it. ${ }^{55}$

50 Hasselbacher (n 1); C Moore 'Women and domestic violence: The public/private dichotomy in international law' (2003) 7 International Journal of Human Rights 93; C Chinkin 'A critique of the public/private dimension' (1999) 10 European Journal of International Law 387.

51 Moore (n 50).

52 As above.

531979,1249 UNTS 13.

54 CEDAW Committee General Recommendation 19 UN Doc A/47/38 (1992) para 9.

55 General Recommendation 19 indicates that the Convention does not apply only to actions by state actors but includes those by private persons where the state fails 'to act with due diligence to prevent violations of rights or to investigate and punish acts of violence and for providing compensation'. CEDAW Committee (n 54). 
A year after General Recommendation 19 was released, in 1993, the Declaration on the Elimination of Violence against Women (DEVAW) was also published by the UN General Assembly (UNGA). The DEVAW imposed an obligation on states to exercise due diligence to prevent gender-based violence perpetrated by the state itself or by non-state actors. ${ }^{56}$

In 1995 the Beijing Platform for Action was introduced. 57 The Platform for Action contained action plans for governments, regional and international organisations and non-governmental organisations (NGOs) to research and come up with statistics on violence perpetrated against women, including domestic violence. 58

In 1999 the UNGA adopted the Optional Protocol to CEDAW. ${ }^{59}$ The Protocol, which entered into force in December 2000, allows women to submit complaints of violations of their rights to the CEDAW Committee upon the exhaustion of all available domestic remedies. $^{60}$ Two of the early decisions of the CEDAW Committee on domestic violence are $A T \vee$ Hungary ${ }^{61}$ and Goekce (Deceased) v Austria (Goekce case). ${ }^{62}$

In $A T \vee$ Hungary, AT filed a communication with the CEDAW Committee claiming to have been a victim of a continuum of domestic violence acts for the previous four years. AT's case was that her common law husband had threatened to kill her and to rape their two children. The husband, LF, had also for three years failed to pay child support. There were ten medical certificates to prove different incidents of physical abuse to which AT had been subjected by LF. AT also stated that under Hungarian law there were no protection orders or restraining orders. ${ }^{63}$

The Committee found that the remedies afforded to victims of domestic violence under Hungarian laws were insufficient and the existing procedures were also ineffective. Hungary was found to have fallen short of its obligation under articles 2(a), (b) and (e) of

56 Declaration on the Elimination of Violence against Women, GA Res 48/104, 20 December 1993, art 4(c) (DEVAW).

57 The action plan was adopted at the United Nations Fourth World Conference on Women held in Beijing, China from 4 to 15 September 1995. Thirty thousand women attended the conference. B Roberts 'The Beijing Fourth World Conference on Women' (1996) 21 The Canadian Journal of Sociology 237.

58 'Report of the Fourth World Conference on Women' Beijing, 4-15 September 1995 A/CONF 177/20/Rev 1.

59 UN General Assembly 'Optional Protocol to the Convention on the Elimination of All Forms of Discrimination Against Women' 1996, 2131 UNTS 83, https://www. refworld.org/docid/3ae6b3a7c.html (accessed 18 September 2018).

60 Optional Protocol to CEDAW (n 22) arts $2 \& 4(1)$.

61 CEDAW Communication 2/2003, UN Doc CEDAW/C/32/D/2/2003.

62 CEDAW Communication 5/2005, UNDoc CEDAW C/39/D/5/2005.

63 AT v Hungary (n 61). 
CEDAW, ${ }^{64}$ although Hungary had taken steps towards instituting a comprehensive action programme against domestic violence. The reason for the decision was that the comprehensive action programme against domestic violence was yet to address the violations having been experienced by AT. AT's rights under articles 5 (a) and 16 of CEDAW were also found to have been violated. ${ }^{65}$ The Committee made recommendations to Hungary to ensure that AT's physical and mental integrity as well as the safety of AT and her children were guaranteed. The Committee, among others, stated: 66

Women's human rights to life and to physical and mental integrity cannot be superseded by other rights, including the right to property and the right to privacy ... [T] he Committee concludes that the obligations of the state party ... remain unfulfilled and constitute a violation of the author's human rights and fundamental freedoms, particularly her right to security of person.

In Goekce, ${ }^{67}$ ?ahide Goekce, an Austrian citizen, suffered various forms of domestic violence and threats of violence by Mustafa Goekce, her husband, over a period of three years (1999 to 2002). The police, the public prosecutor and other state institutions in charge of protection against violence were aware of the violence that Mustafa perpetrated against his wife. Although a number of orders were issued against Mustafa and actions were taken to prevent the violence and to protect ?ahide from her husband, it was on record that at one time ?ahide refused to testify against her husband and specifically asked the Court not to punish him. On 7 December 2002 Mustafa shot and killed ?ahide with a handgun in the presence of their two daughters. A few hours before her untimely death, ?ahide made an emergency call, but the police did not send a patrol car to the scene of the crime. Mustafa surrendered to the police two and half hours after the shooting and currently is serving a sentence of life imprisonment at an institution for offenders with mental disorders. ${ }^{68}$

Austria's contentions inter alia were that by the deceased's failure to cooperate with state authorities to prosecute her husband, she did not exhaust domestic remedies; the deceased also insisted on keeping her family life private and refused to request an interim injunction against her husband. Furthermore, arresting, detaining, prejudging and punishing a person without reasonable suspicion of an imminent

64 Art 2(a) obligates states to embody the principle of gender equality in their national constitutions, laws or any means possible. Under art 2(b) states are to use all means - legislative, sanctions or otherwise - to prohibit discrimination against women. States have the responsibility to use all appropriate measures to eliminate discrimination against women by any person, organisation or enterprise.

65 Art 5(a) requires states to use all means to modify any social or cultural patterns with the view of eliminating customary stereotypes and prejudices about gender roles. Under article 16 states are charged with the duty to ensure that discrimination against women in marriage and family matters is eliminated. 
threat or act of domestic violence would violate the fundamental rights of the person, such as the right to a fair trial, and will be contrary to the presumption of innocence as well as the rule of law. ${ }^{69}$

In response, the complainants argued that the alleged uncooperative attitude of Sahide was a once-off event at a time when she truly thought she risked losing her children should she proceed to testify against her husband. Sahide, who most likely suffered from the Stockholm syndrome, ${ }^{70}$ should not be blamed as at that material time she was unable to draw the line between psychological, economic and social factors. ${ }^{71}$

The CEDAW Committee acknowledged the comprehensive domestic violence protection framework of Austria in terms of its legislation, criminal and civil law remedies, awareness, education and training programmes, shelters, counselling sessions for victims and work with perpetrators. However, the Committee pointed out that a comprehensive system alone would not do, and that the system had to be supportive as well, in order for the victims of domestic violence to fully enjoy their fundamental rights and freedoms. To make the system supportive, the CEDAW Committee mentioned that state actors must adhere to the due diligence obligations of the state.

The CEDAW Committee further illustrated how Austria had failed to exercise its due diligence to protect Sahide, by not responding to Sahide's emergency call despite the history of conjugal violence that had occurred between the two. Austria, therefore, was advised to prevent and respond to violence against women by strengthening the implementation and monitoring of its laws against violence through the exercise of due diligence. As part of its recommendations, the CEDAW Committee expressly stated that 'in all actions taken to protect women from violence, due consideration is given to the safety of women, emphasising that the perpetrator's rights cannot supersede women's human rights to life and to physical and mental integrity'. ${ }^{72}$

Austria was found to be in violation of articles 2(a), (c)-(f) and 3 of CEDAW read with article 1 of CEDAW and General Recommendation 19 of the CEDAW Committee, together with the rights of the deceased to life and physical and mental integrity.

69 As above.

70 According to Merriam-Webster, Stockholm syndrome is the psychological tendency of a hostage to bond with, identify with, or sympathise with his or her captor: Merriam-Webster https://www.merriam-webster.com/dictionary/Stockhom\%20 syndrome (accessed 29 October 2018). The Cambridge English dictionary also defines Stockholm syndrome as the situation when a person who has been taken prisoner starts to like or trust the person or people who have taken them: Cambridge advanced learner's dictionary and Thesaurus https://dictionary. cambridge.org/dictionary/english/stockholm-syndrome (accessed 29 October 2018).

71 Goekce case (n 62) para 5.4.

72 Goekce case para 12.3. 
At the regional level, the Inter-American Commission on Human Rights (Inter-American Commission), which has a well-developed jurisprudence on domestic violence cases, found Brazil to have failed to prevent, prosecute and convict for acts of domestic violence in the case of Maria de Penha Maia Fernandes $v$ Brazil $^{73}$ (Fernandes case). The complainant had suffered acts of violence, including attempted murder, perpetrated by her then husband, Marco Antonio Heredia Viveiros, in the period between May and June 1983. As a result the complainant had become a paraplegic. The complainant's case was that the Brazilian justice system had failed in its duty to ensure equal protection $^{74}$ and judicial protection ${ }^{75}$ since it unduly delayed the final ruling against the perpetrator for more than 15 years. The complainant further added that her complaint was not an exception, but rather that it formed part of the systematic impunity associated with domestic violence acts against women in Brazil. ${ }^{76}$

The Inter-American Commission held that Brazil had violated its duty to ensure judicial protection and equal protection under the American Convention on Human Rights (American Convention) by failing to properly prosecute cases of domestic violence against women. The Commission recommended that Brazil complete the prosecution of Antonio by conducting an effective investigation. It also recommended that the state should provide adequate compensation for the victim. Also, measures should be instituted to eliminate the condonation of domestic violence against women by the state. 77

Similarly, the European Court of Human Rights (European Court) in Opuz $v$ Turkey $^{78}$ found Turkey liable for domestic violence for failing to exercise due diligence in protecting victims and prosecuting the perpetrator. In this case the complainant, Nahide Opuz, and her mother had been subjected to years of domestic violence by Nahide's husband. As a result her husband eventually killed her mother. The two victims had earlier made several reports to the Turkish law enforcement personnel, which yielded very little response. Nahide contended that the incompetence of the Turkish law enforcement was a violation of her right to be free from torture, cruel, inhuman and degrading treatment and gender discrimination as well as her mother's right to life.

73 Inter-American Commission on Human Rights 2000, Case 12.051, IAm Comm of HR, Report 54/01, OEA/Ser L/V/II.111 Doc.20 Rev 704.

74 Organisation of American States (OAS) 'American Convention on Human Rights' Pact of San José', Costa Rica 1969 (American Convention) art 24.

75 Art 25 American Convention.

76 The IACHR found that in Brazil, 70\% of domestic violence complaints that give rise to criminal liabilities are put on hold and hardly any conclusion is reached on them. Of the $30 \%$ that are concluded, only $2 \%$ result in the conviction of the perpetrators: Goekce case (n 62) para 49.

77 Fernandes case (n 73).

78 App No 33401/02, Eur CtHR (2009). 
The European Court held that Turkey indeed had failed to exercise due diligence in protecting the victims, and held in favour of Nahide. The decision served as a gateway for providing a remedy for domestic violence victims in international law in Europe. ${ }^{79}$

In the African system, the Protocol to the African Charter on Human and Peoples' Rights on the Rights of Women in Africa (African Women's Protocol) was adopted in 2003 and entered into force in 2005. As at early 2018, 41 out of 54 African countries had ratified the Protocol. The African Commission on Human and Peoples' Rights (African Commission) is the body in charge of the implementation of the African Women's Protocol. The Protocol, like CEDAW, does not make express mention of 'domestic violence' but its application to domestic violence is inferred from the definition of 'violence against women'. Violence against women, according to the Protocol, means 'all acts perpetrated against women which cause or could cause them physical, sexual, psychological, and economic harm, including the threat to take such acts' ${ }^{80}$ In addition, the Protocol places a duty on states to 'take appropriate and effective measures to enact and enforce laws to prohibit all forms of violence against women ... whether the violence takes place in private or public ${ }^{\prime}{ }^{81}$

After more than 15 years since its adoption and 11 years of being in force, the ECCJ only made its first pronouncement on the African Women's Protocol in the last quarter of 2017,82 and its first domestic violence decision ${ }^{83}$ on the Protocol in the second quarter of 2018. The latter is the subject matter of this article.

In feminists' and scholars' circles, some have labelled domestic violence in a manner that fits the scope of public international law. ${ }^{84}$ Meyersfeld proposed a category of extreme forms of domestic violence that need international attention which she called 'private torture'.85 Meyersfeld also proposes the label 'systemic intimate

79 S Choudhary 'Legal recourse to domestic violence: European perspective through ECHR decision (Opuz $v$ Turkey)' https://ssrn.com/abstract=2177522 (accessed 29 October 2018).

80 African Union Protocol to the African Charter on Human and Peoples' Rights on the Rights of Women in Africa (African Women's Protocol) (2003) art 1(j).

81 Art 4(2)(a) African Women's Protocol.

82 Dorothy Njemanze \& 3 Others v Federal Republic of Nigeria ECW/CCJ/JUD/08/17.

83 Mary Sunday case (n 3).

84 B Meyersfeld 'A theory of domestic violence in international law' JSD thesis, Yale Law School, 2016 http://digitalcommons.law.yale.edu/ylsd/3 (accessed 18 July 2018).

85 Meyersfeld ( $n$ 22). Other labels for domestic violence aimed at placing this form of violence within the public sphere include 'terrorism', explaining domestic violence as involving calculated acts that harm victims psychologically and physically: Meyersfeld ( $n$ 84), citing J Fedler 'Lawyering domestic violence through the Prevention of Family Violence Act 1993: An evaluation after a year in operation (1995) 112 South African Law Journal 231; and 'patriarchal terrorism' which is interpreted as an extreme form of domestic violence: Meyersfeld ( $n$ 84) 99, citing MP Johnson 'Patriarchal terrorism and common couple violence: Two forms of violence against women' (1995) 57 Journal of Marriage and the Family 283. 
violence' as those manifestations of domestic violence that constitute human rights violations in international law. According to her, 'systemic intimate violence' has elements that merit international intervention. Acts of domestic/intimate violence can be classified as 'systemic' when they are severe to a standard that 'shocks human conscience'; the harm is continuous and hybrid in nature as opposed to once-off acts; and the state condones such systematic abuses by its inaction, which often is demonstrated by the lack of supportive welfare systems, inadequate healthcare services, and a lack of access to justice in the form of either police services or the courts. ${ }^{86}$

The constitutional right to privacy was also interpreted by theorists in a way that affirms the safety of women in the domestic setting rather than to oppose or interfere with the privacy of their home. ${ }^{87}$ Thus, the right to privacy has been construed to mean not only the right to be free from intrusion, but 'linked affirmatively to liberty, the right to autonomy and self-determination' ${ }^{88}$

The UN Commission on Human Rights (UNCHR) in 1994 appointed a Special Rapporteur on Violence Against Women. The Special Rapporteur, Ms Radhika Coomaraswamy, delivered her first report in 1996 in which she advocated the recognition of domestic violence as a 'human rights concern rather than as a mere domestic criminal justice concern'. ${ }^{89}$ She argued for conceptualising domestic violence as 'torture', and that domestic violence could constitute torture or cruel, inhuman and degrading treatment depending on the severity and prevailing circumstances that create state responsibility. ${ }^{90}$ The argument of the Special Rapporteur was based primarily on the gendered nature of domestic violence in concert with the inaction of states which condones the perpetuation of the violence. ${ }^{91}$ The Special Rapporteur, therefore, came up with a framework for a model legislation on domestic violence. ${ }^{92}$ The purpose of the model framework is to ensure state compliance with international standards (including due diligence) by sanctioning domestic violence. Thus, by the obligations contained in the model framework, the building blocks for determining the minimum threshold for compliance with the due diligence standard were laid.

\footnotetext{
86 Meyersfeld ( $n$ 84) 125.

87 Meyersfeld (n 84) 100.

88 Meyersfeld ( $n$ 84).

89 Coomaraswamy (n 34) para 29.

90 Coomaraswamy (n 34) para 42.

91 As above.

92 Framework for Model Legislation on Domestic Violence, Doc E/CN.4/1996/53/ Add.2 2 February 1996.
} 


\subsection{State responsibility and the due diligence standard as applicable to domestic violence}

The role of the due diligence standard in assigning state responsibility for gender-based violence, particularly those acts that occur in the private sphere, such as domestic violence, is an instrumental and appealing development. This is because states can be held responsible for violations to which states hitherto were not responsive ${ }^{93}$ due to the public/private dichotomy that limited state responsibility to matters considered to be worthy of state intrusion to the exclusion of those matters that were considered private. These often were matters related to the home and family.

The due diligence standard expands the scope of state responsibility for violations occurring in the private sphere in various ways. ${ }^{94}$ First, the due diligence framework challenges the publicprivate dichotomy which for so long had excluded states from incurring responsibility for violations perpetrated by private individuals in the private sphere. The due diligence standard recognises all violations, whether occurring within the private and public sphere, as human rights violations that deserve equal attention by the state. In this regard, state responsibility for private violations such as domestic violence arises not because the private perpetrator's actions are directly imputable to the state, but because the state has failed to exercise due diligence to prevent, protect from, prosecute, punish and/or provide remedies for the victims. ${ }^{95}$

The inaction of the state has been regarded as complicity in and/or de facto permission for the private violation. ${ }^{96}$ The nature of this obligation has been referred to as a 'diagonal obligation', where states have a duty to protect the rights of individuals and groups from violations by non-state actors. ${ }^{97}$ The finding by the CEDAW Committee in $A T V$ Hungary, that Hungary had failed in its duty to exercise due diligence, is consistent with state responsibility arising out of state inertia with respect to putting measures in place to prevent and protect victims of domestic violence.

In conceptualising due diligence in the domestic violence context, Coomaraswamy echoed the idea of state complicity by arguing that the due diligence principle can hold states complicit in systematic failures in protecting persons from private violence, and requires states to provide and enforce adequate remedies to victims of private

93 Goldscheid \& Liebowitz (n 2); Ertrük (n 35).

94 Goldscheid \& Liebowitz (n 2).

95 Velasquez case (n 24) para 173.

96 Goldscheid \& Liebowitz (n 2); Crawford \& Olleson (n 17); Manjoo (n 39), citing R McCorquodale \& P Simons 'Responsibility beyond borders: State responsibility for extraterritorial violations by corporations of international human rights law' (2007) 70 Modern Law Review 598618.

97 Goldscheid \& Liebowitz (n 2), citing JA Hessbruegge 'Human rights violations arising from conduct of non-state actors' (2005) 11 Buffalo Human Rights Law Review 25. 
violence. $^{98}$ In her view, the complicity of a state in domestic violence is made manifest where a state fails to take the minimum steps necessary to protect the victims of a human rights violation. ${ }^{99}$ The state by its pervasive inaction creates a conspiracy of silence with perpetrators who continue to abuse their victims. ${ }^{100}$ The mere existence of legal systems and sanctions against domestic violence were not sufficient under the due diligence standard. Rather, the state had the obligation to "effectively ensure" that incidents of [domestic] violence are actually investigated and punished'. ${ }^{101}$ This is why in the Goekce case Austria was found to have breached the due diligence standard although, far from being a 'systematic failure' or 'pervasive non-action',102 it had a comprehensive system to protect victims of domestic violence. The decision by the CEDAW Committee in this case resonates with the assertion that it takes more than the mere existence of a legal system for a state to discharge its due diligence obligation to prevent, protect from and punish. There is an obligation to 'effectively ensure' that domestic violence is actually investigated and punished. ${ }^{103}$

Second, the due diligence standard expands state responsibility by its insistence on prevention in addition to the traditional efforts to protect and prosecute, which often are the core of international responsibility. The obligation on a state to prevent is helpful particularly in cases of domestic violence as it shifts the obligations of states from becoming entirely reactionary in nature to being prevenient as well. Thus, due diligence ensures that states protect individuals (individual due diligence) and prevent the continuous occurrence of human rights violations (systemic due diligence). ${ }^{104}$

98 Coomaraswamy (n 34).

99 As above.

100 Henkin et al (n 34). Some scholars have taken issue with Coomaraswamy's view on state complicity in domestic violence at international law. It is their view that state inaction to prevent, investigate and punish domestic violence does not make them complicit in the violence, although state inaction in such matters constitutes independent wrongful actions in international law. To these scholars, there is a need to distinguish between the domestic violence act of the private actor and the inaction of the state: Meyersfeld (n 22) 260, citing A Freeman The international responsibility of states for denial of justice (1938) 20.

101 Coomaraswamy (n 34) para 37.

102 Coomaraswamy (n 34).

103 Coomaraswamy para 37.

104 Manjoo ( $n$ 39). Manjoo in her report emphasised the need to carve out a framework for the responsibility of states to exercise due diligence. She advocates distinguishing between the types of state responsibility to act with due diligence rather than merging them. Manjoo, therefore, introduces 'individual due diligence' and 'systemic due diligence'. She explains individual due diligence as the 'obligations states owe to particular individuals, or groups of individuals to prevent, protect, punish and provide effective remedies on a specific basis'. According to her individual due diligence is flexible because the state's due diligence obligation is ultimately to meet the needs and desires of the affected individual. Systemic due diligence, on the other hand, is the obligation of states to 'ensure a holistic and sustained model of prevention, protection, punishment and reparations for acts of violence against women'. 
This is why in the Fernandes case the Inter-American Commission stated that a violative act may lead to state responsibility 'not because of the act itself, but because of the lack of due diligence to prevent the violation or respond to it as the Convention requires' ${ }^{105}$

Another way in which the due diligence standard expands state responsibility is by requiring states to dig deeper to tackle the root causes of domestic violence, which are the social or cultural patterns that create stereotypes and prejudices about gender roles. This forms part of the duty to prevent by educating and creating awareness on gender equality. Violence against women and domestic violence, for that matter, are directly linked to gender discrimination. To this end, taking steps to eliminate gender discrimination will lead to eliminating domestic violence against women. ${ }^{106}$

On building legal minimums for the due diligence standard, Meyersfeld proposes three factors to consider in determining the minimum threshold below which a state will be deemed to have failed to comply with the due diligence standard, namely, the nature of the right; ${ }^{107}$ the practical resources and capabilities of the country; ${ }^{108}$ and the repetition of aggregate omissions. ${ }^{109}$ Coomaraswamy in her 1999 report also attempted to develop some factors for assessing state compliance with the due diligence standard, namely, the ratification of all human rights instruments including CEDAW; the existence of constitutional authority that guarantees equality for women and prohibits violence against women; the existence of national legislation and/or administrative sanctions that adequately

105 Fernandes case (n 37) (my emphasis). The IACHR in the Fernandes case was guided by the due diligence principle as explained and discussed in the Velasquez case. Also, in Claudia Isabel Velasquez Paiz et al v Guatemala Case 12.777 No 53/13 (2015), the IACHR stated that '[s]tates should adopt comprehensive measures to comply with due diligence in cases of violence against women. In particular, they should have an appropriate legal framework of protection that is enforced effectively, and prevention policies and practices that allow effective measures to be taken in response to complaints.'

106 Goldscheid \& Liebowitz (n 2).

107 According to Meyersfeld, the right at stake when it comes to domestic violence in international law is the right to be free from 'systemic [domestic] violence'. She defines 'systemic [domestic] violence' as involving the following elements: (a) severe emotional or physical harm or threat; (b) a continuum of violence rather than a one-off incident; (c) committed predominantly by men against women within an intimate relationship; (d) victim unable to access legal assistance due to her isolation, incapacitation or general vulnerability; and; (e) the violence is systemic in nature - occurring in a society where the state has failed to provide the minimum facilities necessary to compensate the violence. Meyersfeld (n 84) 111.

108 Meyersfeld argues that the due diligence standard fluctuates depending on the resource capital (social, political and economic) of each state. This notwithstanding, women's rights and interests must remain a priority for states so long as it is 'reasonable and progressive to do so'. Meyersfeld ( $\mathrm{n} 84$ ).

109 This relates to how actionable omission will be determined based on the nature of the right and the resources of the state in question. State liability will not be well founded if its justice system is not able to protect individuals from all forms of violence. Those cases of gender-based violence that are extreme and systemic in nature are those that states should pay attention to. 
remedy women victims of violence; the existence of policies or plans of action that deal with violence against women; the sensitivity of the criminal justice system to issues regarding violence against women; ${ }^{110}$ the existence of support systems for women victims of violence; education and awareness programmes on violence against women as a human rights violation; and the collection of data and statistics on violence against women. 111

Clearly, the efforts to consider domestic violence as an international human rights concern rather than as a domestic criminal justice issue have successfully changed the dynamics of state responsibility by the creation of international norms that impose an obligation on states to prevent and to protect individuals from violence perpetrated by private persons and to punish such private actors. The due diligence obligation is one of means rather than results. That is, the perpetration of domestic violence will not be interpreted as a failure by the state, but rather, the inadequacy of appropriate measures to prevent, protect from or punish will be construed as a state failure for which the state will incur liability. ${ }^{112}$

The purpose of this part of the article has been to set out the underlying concepts and principles on which the Mary Sunday case is examined. This part began with an overview of the traditional notion of state responsibility, which was limited to state actors, highlighting the way in which the due diligence standard was used by the courts and the efforts by feminists to expand the traditional view of state responsibility. The effect is that, by institutionalising the due diligence standard, states now are accountable in international law for the actions and inactions of private individuals as well. This expansive notion of state responsibility through due diligence has been especially helpful in addressing violence against women that often occurs in private, such as domestic violence. This part, therefore, concluded with the way in which domestic violence, through the operation of due diligence in expanding state responsibility incorporated into international documents, international and regional court decisions and feminist scholars, has been raised to the level of a violation in international human rights law for which states can be held responsible. Against this background, the remainder of this article will focus on how these have been weaved into the African human rights system, using the ECCJ and the Mary Sunday case as a case study. The next part of the article gives a brief overview of the ECCJ.

110 On this factor, Coomaraswamy asks further questions: What is police practice? How many cases are investigated by the police? How are victims dealt with by the police? How many cases are prosecuted? What type of judgments are given in such cases? Are the health professionals who assist the prosecution sensitive to issues of violence against women?

111 E.CN.4/1999/68.

112 Goldscheid \& Liebowitz (n 2). 


\section{The ECOWAS Court}

Established in 1991, ${ }^{113}$ the Economic Community of West African States Community Court of Justice (ECCJ) has the mandate to interpret and determine the legality of and member states' compliance with all instruments of the Community. ${ }^{114}$

In 2005 the Court's mandate was expanded to determine human rights violations through the adoption of the Supplementary Protocol, ${ }^{115}$ which since has remained a substantial part of its operations. There neither is a fixed law particularising the scope and nature of the Court's human rights mandate, nor is there a specific index of rights assigned to the Court. Consequently, operating on the basis of the commitment of member states to recognise, promote and protect human rights, ${ }^{116}$ the Court has through case law delimited its human rights mandate. For example, the Court exercises it human rights mandate in accordance with all international instruments to which ECOWAS member states are parties. ${ }^{117}$ Also, applications to the Court that do not clearly specify an alleged human rights violation are not admissible. ${ }^{118}$ Again, since the Supplementary Protocol did not specify the types of human rights violations over which the Court has competent jurisdiction, the Court has delimited its jurisdiction to human rights violations of an international character. ${ }^{119}$

The Supplementary Protocol has allowed individuals to bring actions for human rights violations provided their applications are not anonymous and have not been brought before any other international court. ${ }^{120}$ Typical of the ECC) is the fact that, unlike other comparable regional courts where the exhaustion of domestic remedies is a prerequisite for obtaining audience in the court, there is no such barrier in the case of the ECCJ. Individuals can walk straight to the ECC J and bypass all local remedies available. ${ }^{121}$ This distinctive feature of the Court increases accessibility, especially of individuals to justice where it eludes them in their home countries. For this reason, the

113 Revised Treaty of the Economic Community of West African States1993 art 15.

114 Protocol A/P1/7/91 on the Community Court of Justice art 9.

115 Supplementary Protocol A/SP.1/01/05 art 3(4). D Abebe 'Does international human rights law in African courts make a difference?' (2017) 56 Virginia Journal of International Law 527. ST Ebobrah 'Critical issues in the human rights mandate of the ECOWAS Court of Justice' (2010) 54 Journal of African Law 1.

116 Supplementary Protocol (n 115) art 4(g).

117 SERAP v Federal Republic of Nigeria ECW/CCJ/ JUD/18/13 para 28.

118 Musa Leo Keita $v$ The Republic of Mali ECW/CCJ/JUD/03/07.

119 Peter David v Ambassador Rolph Uwechue ECW/CCJ/RUL/03/10.

120 Supplementary Protocol (n 115) art 4(d).

121 Prof Moses Essien $v$ The Gambia ECW/CCJ/APP/12/11 (2012) para 31. In this case the defendant state argued that exhaustion of local remedies as stated in art 50 of the African Charter was applicable to the ECC). The ECCI rejected this argument and explained that art 50 did not apply to the ECC). The Court stated that 'access to this Court is not subject to exhaustion of local remedies as envisaged by the customary international law on the point'. 
$\mathrm{ECCl}$ is a promising platform for administering the rights of women in West Africa.

\section{The Mary Sunday case}

The case of IHRDA \& WARDC (on behalf of Mary Sunday) $v$ The Federal Republic of Nigeria (Mary Sunday case) ${ }^{122}$ is the first ever domestic violence case decided by the ECC). It was decided on 17 May 2018. The petition was filed on 24 August 2015 by the Women Advocates Research and Documentation Centre (WARDC) and the Institute for Human Rights and Development in Africa (IHRDA) on behalf of Ms Mary Sunday against the Federal Republic of Nigeria.

\subsection{The facts}

On 24 August 2012 the victim, Ms Mary Sunday and her fiancé, Corporal Gbanwuan, had an altercation that resulted in the victim suffering some physical injuries.

It was Ms Sunday's case that during the wrangle the corporal had beaten her with his fists the entire time. She also indicated that she sought refuge in their neighbour's kitchen, where the corporal poured hot oil over her and scalded her.

By contrast, the police's version of the facts revealed that according to their investigations, it was rather Ms Sunday who attempted to pour the hot oil on her fiancé, but she ended up scalding herself in the process. She was found by the police to have provoked the unfortunate events.

The plaintiff claimed the following violations against the Federal Republic of Nigeria: (a) a violation of her right to an effective remedy; (b) a violation of her right to health; (c) a violation of her right to work; and (d) discrimination with respect to her being a woman. She claimed a sum of 20 million against the Republic of Nigeria as compensation for damages suffered.

The Federal Republic of Nigeria filed a preliminary objection challenging the jurisdiction of the ECCJ to hear the case. However, this objection was rejected by the Court, which on 7 December 2016 ruled that it had the competence to hear the case. ${ }^{123}$

The defendant state argued that it could not be held liable for the violation alleged by the plaintiff since the said violent act was strictly of a private nature and did not involve a public official or agent acting in the course of his official duties or as a consequence of such duties.

122 The original judgment in the case was delivered in French. References and quotations from the case used in this article are from the English translation retrieved from International Human Rights and Development in Africa (IHRDA), one of the two organisations that filed the action on behalf of Mary Sunday.

123 Ruling ECW/CCJ/APP/26/15. 


\subsection{The Court's judgment}

The three-member panel Court dismissed the plaintiff's pleas for a violation of her right to health and discrimination on the grounds of gender. The ECCI, however, found in favour of the plaintiff in respect of her plea based on the right to an effective remedy, and awarded the sum of ? 15 million as compensation.

\section{Analysis of the ECOWAS Court's due diligence jurisprudence in Mary Sunday}

The Mary Sunday case is profound for synthesising the application of the due diligence principle in determining state responsibility for domestic violence in the African human rights framework. Although there is no express mention of 'due diligence' in the case - a variant 'appropriate diligence' is used once in relation to the right to health inferences of its application can be drawn from the reasoning of the Court, which inferences are consistent with the derivatives of the due diligence principle as discussed above. The case is particularly important to ascertain the jurisprudence of the ECCJ concerning the forms of domestic violence that merit international intervention and those that do not, and the distinctions that the ECCJ draws between the human rights violations for which states can incur responsibility and those for which they cannot, as well as the circumstances under which states can incur responsibility.

The remainder of this part of the article focuses on ascertaining how the due diligence principle came into play to hold Nigeria liable or otherwise regarding the human rights issues that were raised in the Mary Sunday case, and how these inform the burgeoning due diligence jurisprudence of the ECCJ for state responsibility in domestic violence cases.

\subsection{State obligation to exercise due diligence to prevent discrimination based on gender}

The ECCJ first addressed Ms Sunday's claim that Nigeria's refusal to pursue proceedings against Corporal Gbanwuan despite the violence to which she had been subjected makes the state responsible for discrimination on the grounds of gender under articles 2 and 18(3) of the African Charter on Human and Peoples' Rights (African 
Charter); ${ }^{124}$ article 2 of the African Women's Protocol; ${ }^{125}$ article 2 of CEDAW; ${ }^{126}$ articles 2(1) and 6 of the International Covenant on Civil and Political Rights (ICCPR); ${ }^{127}$ and article 2 of the Universal Declaration of Human Rights (Universal Declaration). ${ }^{128}$ Nigeria argued that no human rights violation could be attributed to it since the alleged violent act was committed by the state official acting in his private capacity. Nigeria also contended that the acts constituted domestic violence that could only be challenged in the context of being the individual responsibility of Corporal Gbanwuan.

Here, we clearly see the state using in its defence the age-old trump card of public/private duality with which the Court agreed. The Court explained that the nature of the acts complained of was not systematic such as to allow their 'deliberately discriminatory character to be confirmed'. ${ }^{129}$ In other words, the actions leading to the case were confined within the private sphere - conjugal violence - which had nothing 'general' or 'systematic' about it. The events related to an individual and not to a 'gender', which the Court indicated encompassed plurality. The Court added that the fact that the perpetrator in the instant case was a state official had no bearing on state responsibility as he was acting purely in his private capacity. The $E C C J$ added that even if the acts were to have been committed in his official capacity, they should have been dealt with as assaults, or as being unrelated to the duties of an agent of the police force. For these reasons the ECCJ found Nigeria not liable for violating the right to be free from gender discrimination but directed that this aspect of the matter should be dealt with at the national level where the perpetrator will be held personally accountable.

Mary Sunday's claim invoked the due diligence duty of Nigeria to prosecute and convict for violations. She used Nigeria's failure to execute this duty effectively as grounds for discrimination based on gender, but this was where she was at fault. The insistence of the

124 Art 2 provides: 'Every individual shall be entitled to the enjoyment of the rights and freedoms recognised and guaranteed in the present Charter without distinction of any kind such as race, ethnic group, colour, sex, language, religion, political or any other opinion, national and social origin, fortune, birth or any status.' Art 18(3) provides: 'The state shall ensure the elimination of every discrimination against women and also ensure the protection of the rights of women and the child as stipulated in international declarations and conventions.'

125 This provision relates to the elimination of discrimination against women through legislative, institutional and other measures necessary. Art 2(1)(d) provides: 'States shall take corrective and positive action in those areas where discrimination against women in law and in fact continues to exist' (my emphasis).

126 The article places an obligation on state parties to pursue by all appropriate means and without delay a policy of eliminating discrimination against women and undertake such steps as are necessary.

127 Art 2(1) provides that state parties will recognise the rights of all persons within its territory and jurisdiction without any kind of distinction whatsoever. Art 6 protects the right to life and guarantees the protection of this right under the law.

128 Art 2 guarantees the rights and freedoms listed in the Universal Declaration to all persons without distinction.

$129 \mathrm{ECW} / \mathrm{CCJ} / \mathrm{APP} / 26 / 15$. 
ECCJ on the non-systematic or non-general nature of the events and, hence, the absence of discrimination based on gender by Nigeria can be reconciled with the literature and case law that require domestic violence acts to be systemic in nature in order to warrant international intervention and incur state responsibility. For example, in the Fernandes case there was evidence in the form of statistical reports to show that the unresponsiveness of the Brazilian justice system towards domestic violence against women was systematic. In the Geokce case and AT $v$ Hungary the domestic violence acts complained of constituted a continuum of harm rather than a once-off event. ${ }^{130}$ Based on the evidence presented, the states and the justice systems of the states in these cases had systematically failed to prevent, protect from, prosecute and punish the violations that the women involved had faced. That was not the case in Mary Sunday.

First, the aggressive act leading to Mary Sunday's injury was a once-off event which was not sufficient to create a continuum of harm for which the resulting pervasive non-action by Nigeria could give rise to international responsibility. Second, there was no evidence or empirical data presented to the ECCJ to show that Nigeria or the justice system in Nigeria had systematically failed to respond to similar cases of violence against women. This plays up one of the underlying principles of the due diligence standard which requires preventive and protective measures by states to be based on accurate empirical data. ${ }^{131}$ The actions of Corporal Gbanwuan in his private capacity could be classified as a violation of Mary Sunday's right to be free from violence against women for which the corporal could be personally liable at the national level. However, his action cannot lead to a direct responsibility of Nigeria as discriminating against women although it gives rise to an indirect responsibility for the failure of Nigeria to provide an effective remedy for Mary Sunday, which the ECCJ found.

The ECCJ's opinion on the public-private dichotomy in domestic violence cases in international law and how it relates to state responsibility departs from the mainstream literature and case law on the subject. The ECCJ was of the view that Nigeria did not incur responsibility because Corporal Gbanwuan, although a state official, was acting in his private capacity. The Court made reference to a hypothetical situation where even if Corporal Gbanwuan was acting in his official capacity, Nigeria still would not have incurred responsibility as he had acted ultra vires. Unless this hypothetical situation and the conclusion therefrom was strictly based on the particular facts of the case where the violent act was not of an international character, the Court's opinion would be inaccurate. This is because the actions of a state official acting in his official capacity, even if he acts ultra vires, are

130 Henkin et al (n 24); Meyersfeld (n 22).

131 Ertrük (n 35). 
imputable to the state. ${ }^{132}$ This should be distinguished from actions of a state official acting in his private capacity, which are not attributable to a state. The advent of the due diligence standard in domestic violence cases makes states responsible for paying attention to violence against women both in the private and public spheres. A failure to prevent, protect from and punish violations within the private sphere may give rise to state responsibility.

\subsection{State obligation to exercise due diligence to protect the right to health care and to appropriate medical care interventions}

It was Mary Sunday's claim that Nigeria had violated her right to health as guaranteed in international law ${ }^{133}$ by refusing to make the necessary health care interventions available to her and failing to provide accessible and available health services.

The ECCJ dismissed this claim on two grounds: First, there was no evidence to show a refusal or delay in providing health care ${ }^{134}$ and, second, there were no reasonable grounds for upholding the claim as to the quality of technical facilities at public hospitals. On the second basis, the Court stated that the quality of technical facilities was heavily dependent on the level of resources available to the state which, in turn, is dependent on the economic development level of the state. There is no uniformity regarding state resources. The ECC] found the hospital services to have shown evidence of 'appropriate diligence and the state [had] not fallen below the standard of what could reasonably be expected of it'.135

Here, the ECCJ demonstrates its application of the due diligence standard to state responsibility. Its finding is consistent with one of the factors in determining the minimum threshold for due diligence which requires the resources of the state to be taken into account. ${ }^{136}$ However, caution should be taken where the issue of resources is involved as there is a risk of states using the lack of resources to escape responsibility. The due diligence standard requires states to do the reasonable minimum to protect against violations of rights.

132 Art 7 ARSIWA (n 5).

133 This ground was based on art 16 of the African Charter; art 14 of the African Women's Protocol; art 25(1) of the Universal Declaration; and art 12 of the International Covenant on Economic, Social and Cultural Rights (ICESCR).

134 On the contrary, Mary Sunday was admitted to the hospital immediately after the incident before she was transferred to another hospital to receive further treatment. Issues of burden of proof which the Court raised is beyond the scope of this article, which focuses primarily on the due diligence aspect of the Court's decision. The burden of proof in gender-based violence generally is the subject matter of another article.

135 Mary Sunday case (n 3).

136 Meyersfeld (n 22). 


\subsection{State obligation to exercise due diligence in providing an effective remedy}

The plea for Nigeria to be held liable for violating Mary Sunday's right to an effective remedy ${ }^{137}$ was the only successful plea. The grounds for the plea was that Nigeria had refrained from an independent and thorough investigation into the matter. In its defence, Nigeria once again raised the private nature of the events as a barrier to incurring liability. The defendant state also added that according to their investigations Mary Sunday had injured herself and, therefore, there was no room for state liability. ${ }^{138}$

The ECCJ rejected the defence of Nigeria by pointing out that the private nature of the incident is not a sustainable reason when it comes to a victim accessing justice and a legal remedy. The Court stated: ${ }^{139}$

It would clearly be futile, as the state of Nigeria has at time indicated in its defence, if the public authority were never required to involve itself in events that are characterised by their private nature. Such a point of view would not only result in leaving certain violent acts committed in a domestic context unpunished ... but this view is further refuted in terms of the progress made within civilised society in order to deal consistently with social violence and to improve the peaceful quality of communal life. The law also remains valid within private dwellings, it does not cancel itself out on approaching the doors to marital homes.

The Court's assertion that the law remains valid in private settings is in sync with Mill's theory on which the public/private divide was partly premised. That is, although state interference in private matters should be minimalist, it is to the exclusion of instances where harm is caused, as in this case. States, therefore, can no longer hide behind the public/private divide to escape responsibility for violations within the private setting.

With regard to the results of the investigation by the police, the ECCJ found it perfunctory. There was no evidence on the dossier indicating a proper questioning of Corporal Gbanwuan. At a glance, the Court found the injuries sustained by Mary Sunday to be indicative of the level of harm to which she had been subjected. The victim had also been informed that upon the death of Corporal Njoku, the officer originally handling the investigation, the dossier for the case had been lost. The Court was of the view that taking into consideration the discrepancies surrounding the incident, the police should not have hastily concluded its investigations so as to dismiss the matter, but rather should have deferred to a national court of competent jurisdiction to resolve the matter in accordance with the

137 This plea was based on art 8 of the Universal Declaration; arts 2(1) \& 2(3) of ICPPR; arts 8 \& 25 of the African Women's Protocol; arts $2 \& 3$ of CEDAW; and arts $12,13 \& 14$ of the Convention Against Torture (CAT).

138 Mary Sunday case (n 3).

$139 \mathrm{ECW} / \mathrm{CCJ} / \mathrm{APP} / 26 / 15$. 
law. ${ }^{140}$ For these reasons, the ECCJ found Nigeria to have been in violation of Mary Sunday's right to access justice.

The finding of the Court is a clear demonstration of the due diligence duty of states to prosecute, punish and provide reparations for victims of violence. A failure to investigate includes a failure to properly investigate. The Court echoed the need for a state to exercise due diligence to investigate seriously and thoroughly. Thus, although Nigeria did not directly incur liability for the violence perpetrated against Mary Sunday, it indirectly incurred responsibility for its failure to provide her with the appropriate legal remedy by conducting serious investigations.

Manjoo's proposal for distinguishing between the types of due diligence is significant here. Nigeria's liability was not found based on its failure to exercise systemic due diligence per se, but rather was premised on its failure to exercise individual due diligence which it personally owed to Mary Sunday to meet her needs of accessing justice. From this perspective, credence is given to Manjoo's proposal that the due diligence principle expands the scope of state responsibility. The distinction also allows for individual victims of domestic violence to be entitled to compensation on the international plane even in cases where the violent acts are not systemic properly so called.

Much as this two-part distinction of due diligence is promising for protecting individual victims of domestic violence, it potentially can cause challenges to the ECC] in particular. As indicated earlier, there is no prior requirement to exhaust local remedies before appearing at the ECCJ. The downside to this, coupled with an advanced individual due diligence jurisprudence, is that over time the ECCJ will be heavily inundated with cases that otherwise could have been resolved at the national level. On the flip side, the open gates to the ECCJ allow victims who find themselves frustrated by state inertia in providing access to justice, as in the Mary Sunday case, to easily access justice. It therefore is recommended that a framework be put in place at the regional level to balance the competing concerns into a complementary model that will serve the interests of justice.

\section{Conclusion}

This article has reviewed the Mary Sunday case with respect to state responsibility for domestic violence in international law through the lens of the due diligence standard. The article also examined the $E C C J$ 's jurisprudence on the due diligence standard as it applies to state responsibility. Although there was no express mention of 'due diligence' in the Mary Sunday case, there is evidence of its application by the ECC] in holding Nigeria accountable. 
The Mary Sunday case is significant for holding states accountable to prosecute the perpetrators of acts of domestic violence which often occur in the private sphere. It serves as a precedent that informs states on the minimum measures required to ensure their compliance with the due diligence standard, particularly as far as the obligation to properly investigate, prosecute and punish perpetrators is concerned. It emphasises the fact that this obligation of states transcends the public/private divide especially where human rights violations are involved. Indeed, the ECCJ is to be applauded for its attempt to explicate the due diligence standard in the African context, which involves that (a) state liability for human rights violations does not arise only in state actions but also in private actions such as domestic violence; and (b) a state's failure to exercise due diligence to prosecute, punish and provide reparation for victims of domestic violence will incur international responsibility.

However, it is observed that for a landmark decision such as Mary Sunday, the ratio on which the decision was made was quite terse. The ECCJ seemed to have rushed through its decision, leaving many issues barely addressed that could have been detailed to cement its jurisprudence. The decision basically reiterated legal provisions in international and regional instruments that were used by the parties without reference to case law either in the region or beyond. Its characteristically pithy comments on the issues arising in the case make it challenging to conduct an in-depth theoretical analysis on the reasoning and jurisprudence of the Court. It is believed that the nature of the Court's judgment is partly attributable to the prevailing judicial system at the regional level which combines the civil and common law systems. It is recommended, therefore, especially in cases of a monumental nature such as Mary Sunday, that the Court goes the extra mile to comprehensively address all issues raised. This is so because if the Court were to substantially contribute to creating ground-breaking changes in society, then far-reaching decisions are essential. 